\title{
A note on the performance and nitrogen output of broiler chickens fed diets with and without meat-and-bone meal formulated to total or digestible amino acid requirements
}

\author{
W. Szczurek ${ }^{1}$ \\ Research Institute of Animal Production, \\ Department of Animal Nutrition \\ 32-083 Balice, Poland
}

(Received 10 June 2003; accepted 28 October 2003)

\begin{abstract}
The aim of the experiment was to determine the potential for the improvement of growth performance and reduction of nitrogen excretion in chickens by formulating practical diets, with or without meat-and-bone meal, on a digestible amino acid basis. From days 22 to 42 chickens were fed isoenergetic diets based either on maize, wheat and soyabean meal and containing $8 \%$ meat-and-bone meal (M) or on maize, soyabean meal, rapeseed meal and faba beans $(\mathrm{P})$. Diets were formulated on a total (Mt and $\mathrm{Pt}$ ) or digestible ( $\mathrm{Md}$ and $\mathrm{Pd}$ ) amino acid basis. No significant differences in performance indices between chickens fed $\mathrm{M}$ diets and those fed $\mathrm{P}$ diets were obtained. Mean daily $\mathrm{N}$ output on diets containing exclusively vegetable ingredients was significantly lower than on $\mathrm{M}$ diets. A similar trend was observed for relative $\mathrm{N}$ output ( $\%$ of $\mathrm{N}$ intake). Body weight gain, feed conversion ratio, and European Performance Index value of chickens fed diets formulated on a digestible amino acid basis were superior $(\mathrm{P} \leq 0.05)$ to those of chickens fed diets based on total amino acids. There was a tendency for both measures of $\mathrm{N}$ output to decrease when diets were formulated on a digestible amino acid basis.
\end{abstract}

KEY WORDS: digestible amino acids, diet formulation, performance, nitrogen output, broiler chickens

\section{INTRODUCTION}

It is well known that the amounts of digestible amino acids (DAA) in feed ingredients are often considerably lower than the total analysed levels of amino acids (TAA). Overprocessing of oilseed meals and meals of animal origin, and

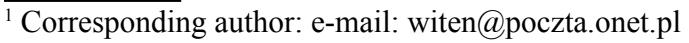


the presence of anti-nutritional factors in some raw materials used in poultry diets greatly reduce digestibility and/or availability of amino acids for protein synthesis (Parsons, 1996). Although the application of DAA values in diets for broilers and laying hens has been of growing interest to nutritionists over the last decade (Johnson, 1992; Waldroup, 2000), there is still little information on the use of DAAs in practical feed formulation.

The objective of this experiment was to determine the potential for the improvement of growth performance and reduction of nitrogen excretion in chickens by formulating practical diets, with or without meat-and-bone meal, on a DAA basis.

\section{MATERIAL AND METHODS}

From one day of age, chickens of a commercial strain (Starbro) were raised on a standard starter type diet. On day 22 the birds were segregated on the basis of secondary sex characteristics and weighed. Birds of uniform body weight were randomly allocated to four dietary treatments and placed in battery cages equipped for the quantitative collection of excreta. Five replicates of ten birds $(5 \hat{\jmath}+5$ + $)$ were assigned to each treatment. From days 22 to 42 chickens were fed ad libitum experimental diets. At the end of the experiment birds were group weighed (each of five replicates per treatment) and their feed intake and mortality were recorded. These data were used to calculate the body weight gain (BWG), feed intake (FI), feed conversion ratio (FCR) and European Performance Index (EPI). During the 4 day collection period (29 to 32 days) feed consumption was monitored, and excreta of birds within a replicate were collected daily. Samples of fresh excreta were analysed for total $\mathrm{N}$ content using the Kjeldahl method (AOAC, 1990).

Four isoenergetic diets (13.4 MJ ME/kg) were prepared (Table 1). The diets were based either on maize, wheat, soyabean meal and meat-and-bone meal (M diets) or on maize and different sources of vegetable protein (P diets). The rates of inclusion of meat-and-bone meal (MBM), rapeseed meal and faba beans were those that could be used in commercial practice. Diets were formulated on a TAA or DAA basis, taking into account dietary levels of TAA suggested in the Poultry Feeding Standards (1996) or these values converted into DAAs using the technique proposed by Dalibard and Paillard (1995). True faecal amino acid digestibility coefficients were derived from Rhone-Poulenc (1993) and Ajinomoto Heartland (2001) tables. Dietary contents of lysine, methionine+cystine and threonine were adjusted using commercially available feed-grade crystalline amino acids. The nutrient content of the diets was calculated according to the chemical composition of raw feedstuffs determined by conventional methods (AOAC, 1990). Amino acids were analysed by HPLC using a Beckman type 126AA System Gold Analyzer. 
TABLE 1

Composition of broiler diets with and without meat-and-bone meal formulated on a total or digestible amino acid basis

\begin{tabular}{|c|c|c|c|c|}
\hline $\begin{array}{l}\text { Composition } \\
\mathrm{g} / \mathrm{kg}\end{array}$ & $\mathrm{Mt}^{1}$ & $\mathrm{Md}^{1}$ & $\mathrm{Pt}^{2}$ & $\mathrm{Pd}^{2}$ \\
\hline \multicolumn{5}{|l|}{ Ingredients } \\
\hline maize & 345 & 346 & 460 & 470 \\
\hline wheat & 322 & 323 & & \\
\hline soyabean meal & 170 & 170 & 120 & 110 \\
\hline meat-and-bone meal & 80 & 80 & & \\
\hline rapeseed meal & & & 150 & 150 \\
\hline faba beans & & & 120 & 120 \\
\hline rapeseed oil & 21 & 21 & 107 & 106 \\
\hline blended animal fat & 42 & 42 & & \\
\hline minerals and vitamins ${ }^{3}$ & 12.40 & 11.55 & 38.05 & 39.20 \\
\hline L-Lys $\mathrm{HCl}(80 \%)$ & 2.70 & 2.25 & 1.54 & 1.57 \\
\hline DL-Met $(99 \%)$ & 3.50 & 2.95 & 2.65 & 2.43 \\
\hline L-Thr $(98 \%)$ & 1.40 & 1.25 & 0.76 & 0.80 \\
\hline \multicolumn{5}{|l|}{ Calculated or analyzed } \\
\hline $\mathrm{AME}, \mathrm{MJ} / \mathrm{kg}^{4}$ & 13.4 & 13.4 & 13.4 & 13.4 \\
\hline crude protein ${ }^{4}$ & 176.0 & 175.0 & 172.0 & 167.0 \\
\hline \multicolumn{5}{|l|}{ Amino acid ${ }^{5}$} \\
\hline Lys & 10.0 & 8.5 & 10.0 & 8.5 \\
\hline Met & 4.4 & 4.1 & 4.4 & 4.1 \\
\hline Met+Cys & 8.1 & 7.0 & 8.1 & 7.0 \\
\hline $\operatorname{Trp}$ & 1.9 & 1.6 & 1.9 & 1.7 \\
\hline Thr & 6.8 & 5.8 & 6.8 & 5.8 \\
\hline Arg & 10.3 & 9.3 & 10.3 & 9.3 \\
\hline
\end{tabular}

${ }^{1}$ diets with meat-and-bone meal formulated on a total (Mt) or digestible (Md) amino acid basis

${ }^{2}$ diets without meat-and-bone meal formulated on a total $(\mathrm{Pt})$ or digestible $(\mathrm{Pd})$ amino acid basis

3 including: limestone, dicalcium phosphate, salt, trace minerals-vitamin premix. Premix provided per kilogram of diet: vit. A $10000 \mathrm{IU}$; vit. $\mathrm{D}_{3} 2000 \mathrm{IU}$; mg: vit. E 50; vit. $\mathrm{K}_{3} 2$; vit. $\mathrm{B}_{1} 1.5$; vit. $\mathrm{B}_{2}$ 5 ; vit. $\mathrm{B}_{6} 3$; vit. $\mathrm{B}_{12} 0.02$; calcium pantothenate 12 ; folic acid 1 ; nicotinic acid 25; biotine 0.1 ; choline chloride 400; Fe 60; Cu 8; Co 0.4; Mn 100; Zn 50; J 0.8; Se 0.2; flavomycin 3; salinomycin 60

${ }^{4}$ calculated on the basis of chemical analysis of feed ingredients

${ }^{5}$ total amino acid values are analysed, digestible amino acid values are calculated on the basis of analysed amino acid composition of raw feedstuffs

Data were subjected to analysis of variance (MANOVA). Treatment means were compared using the LSD test. 


\section{RESULTS AND DISCUSSION}

Overall, there were no significant differences in BWG, FCR and EPI values between chickens fed diets with MBM and those fed diets without MBM. Feed intake (FI) in birds fed on $\mathrm{M}$ diets was higher $(\mathrm{P}=0.02)$ than in those fed on $\mathrm{P}$ diets (Table 2). As a result of the lower dietary crude protein content and the lower FI, mean daily nitrogen output ( $\mathrm{g} \mathrm{N}$ per bird) on diets based solely on vegetable ingredients was significantly lower than on MBM-containing diets. A similar trend $(\mathrm{P}=0.08)$ was observed for relative $\mathrm{N}$ output ( $\%$ of $\mathrm{N}$ intake). Independently of the presence of MBM in diets, average BWG and FCR, and EPI value of chickens fed diets formulated on a DAA basis were superior to those of chickens fed on diets based on TAAs ( $\mathrm{P}=0.03$ to 0.01$)$. There was a tendency for both measures of $\mathrm{N}$ output to decrease when diets were formulated to DAA requirements. However, no significant differences in daily $\mathrm{N}$ output were found for dietary treatments $\mathrm{Mt}$ and $\mathrm{Md}$ and for Pt and Pd.

A limited number of studies have been conducted to demonstrate the advantages of using DAA values of feedstuffs, determined in pretest assays with caecectomized roosters, to formulate broiler diets. In most cases the benefits were seen when chickens during the first three weeks of growth were fed on diets with large amounts of low quality animal meals (Wang and Parsons, 1998) or unusual vegetable protein sources (Fernandez et al., 1995). In contrast, Farrell et al. (1999) using a range of feedstuffs combined into practical least-cost formulations showed that diets based on total or digestible amino acids gave no differences in production parameters of broilers between 22 and 41 days of age. The reason for this, as concluded by authors, may be that the DAA requirements of broilers are not known precisely.

In the present experiment excellent performance indices were obtained on diets with and without MBM formulated according to the chosen specifications for DAAs. The BWG of birds fed the Pt diet was inferior to the Mt and Md diets. However, it is noteworthy that formulation of the Pd diet on a DAA basis yielded BWG that was similar to those obtained on diets Mt and Md. The use of DAAs significantly improved FCR in chickens fed on both $\mathrm{M}$ and P diets. In the case of $M$ diets part of this effect may be explained by lower FI in chickens fed the Md diet. As a result, the European Performance Index calculated for birds receiving diets formulated on a DAA basis was significantly (diet Md) or numerically (diet Pd) higher.

In this experiment the requirements for total and digestible lysine (Table 1) were almost in line with those found by Han and Baker (1994) for optimum FCR of chickens from 3 to 6 weeks of age $(9.9$ and $8.7 \mathrm{~g} / \mathrm{kg}$ for both sexes, respectively). However, the methionine to lysine ratio $(\mathrm{Lys}=100 \%)$ in diets formulated to calculated DAA requirements was higher (48\%) than in diets formulated on a 
TABLE 2

Effect of dietary treatment on body weight gain (BWG), feed intake (FI), feed conversion ratio (FCR), European Performance Index (EPI) value and nitrogen output in broiler chickens

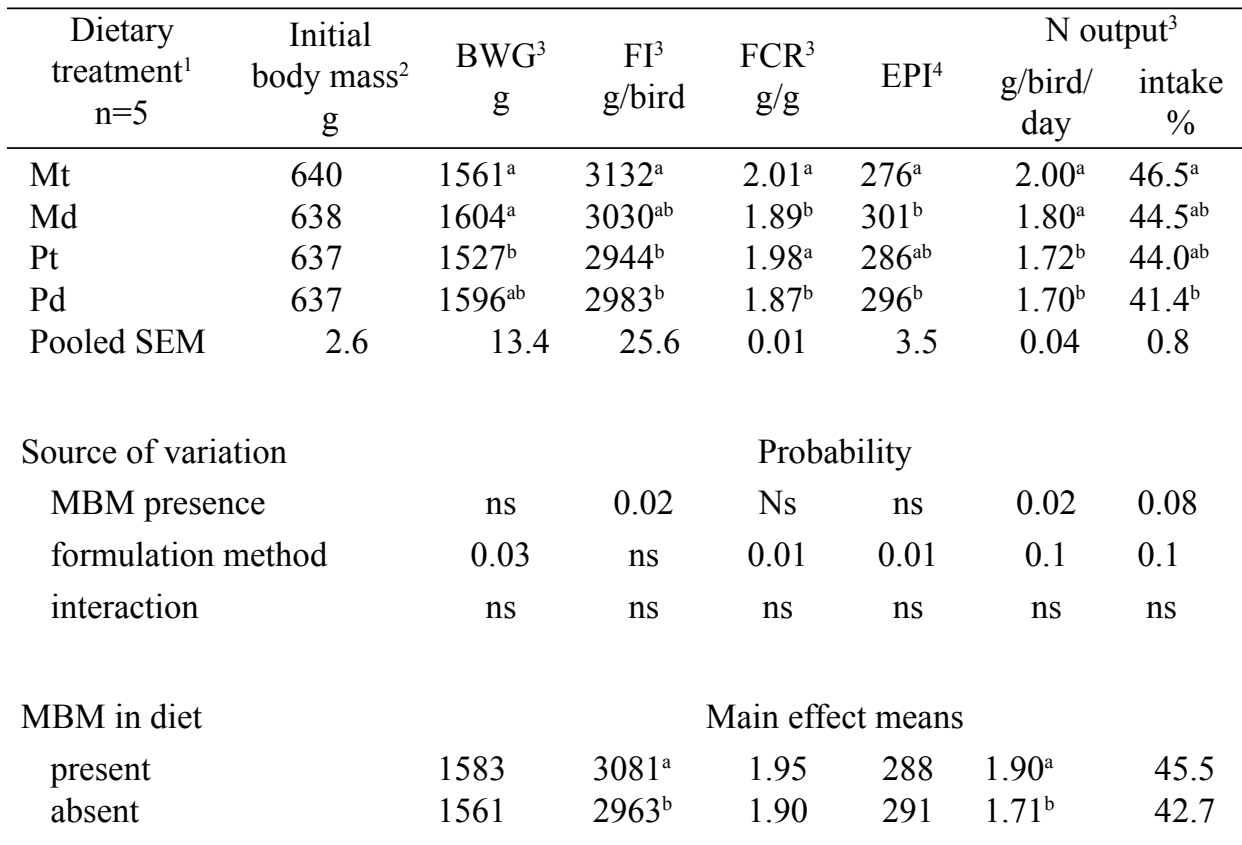

Formulation method

$\begin{array}{lllllll}\text { total amino acids } & 1544^{\mathrm{a}} & 3038 & 1.97^{\mathrm{A}} & 281^{\mathrm{A}} & 1.86 & 45.3\end{array}$

$\begin{array}{lllllll}\text { digestible amino acids } & 1600^{\mathrm{b}} & 3006 & 1.88^{\mathrm{B}} & 298^{\mathrm{B}} & 1.75 & 42.9\end{array}$

${ }^{1} \mathrm{Mt}, \mathrm{Md}$ - diets with meat-and-bone meal (MBM) formulated on a total (Mt) or digestible (Md) amino acid basis; $\mathrm{Pt}, \mathrm{Pd}$ - diets without meat-and-bone meal formulated on a total (Pt) or digestible (Pd) amino acid basis

${ }^{2}$ at 22 day of age

${ }^{3}$ between 22 and 42 days of age

${ }^{4}$ calculated including average intake of starter diet ( $\left.885 \mathrm{~g} / \mathrm{bird}\right)$ and using the following equation: $\mathrm{EPI}=[$ body weight $(\mathrm{kg}) \times$ survival $(\%) /$ age (42 days) $\times \mathrm{FCR}] \times 100$

a,b,A,B means in columns with different letters differ significantly: ${ }^{\mathrm{a}, \mathrm{b}}-\mathrm{P} \leq 0.05,{ }^{\mathrm{A}, \mathrm{B}} \mathrm{P} \leq 0.01$

TAA basis (44\%). It cannot be ruled out that this could be one of the reasons for better feed conversion in birds fed diets formulated to the DAA specifications. In a recent study, Mack et al. (1999) found that the increasing dietary levels of methionine (relative to lysine) significantly improved FCR in Ross broiler chickens.

It is also not unlikely that the benefits of using DAAs could have partially resulted from a discrepancy between actual and calculated dietary DAA contents of experimental diets. It seems probable that for some protein ingredients, the tabular 
digestibility values used might be lower than the actual ones. This highlights the necessity for the further development of information on amino acid digestibility coefficients of a wide range of protein feedstuffs of different origin.

The results of the experiment reported herein indicate that it is possible to use DAA values for more efficient formulation of broiler diets containing meat-andbone meal in an amount that could be used in commercial practice. Restrictions on the use of rendered animal (mammalian) by-products suggest the need for studies to determine optimum conditions for obtaining poultry products using feeds based solely on vegetable protein sources. Considering the results of the present experiment, in which diets containing plant products only were used, it seems that this goal can be attained by adjusting the level of digestible amino acids.

\section{REFERENCES}

Ajinomoto Heartland, 2001. True Digestibility of Essential Amino Acids for Poultry - 2001. (Table). Ajinomoto Heartland Inc., Chicago, IL

AOAC, 1990. Official Methods of Analysis, Association of Official Analytical Chemists. $15^{\text {th }}$ Edition. Arlington, VA

Dalibard P., Paillard E., 1995. Use of the digestible amino acid concept in formulating diets for poultry. Anim. Feed Sci. Tech. 53, 189-204

Farrell D.J., Mannion P.F., Perez-Maldonado R.A., 1999. A comparison of total and digestible amino acids in diets for broilers and layers. Anim. Feed Sci. Tech. 82, 131-142

Fernandez S.R., Zhang Y., Parsons C.M., 1995. Dietary formulation with cottonseed meal on a total amino acids versus a digestible amino acids basis. Poultry Sci. 74, 1168-1179

Han Y., Baker D.H., 1994. Digestible lysine requirement of male and female broiler chicks during the period three to six weeks posthatching. Poultry Sci. 73, 1739-1745

Johnson R.J., 1992. Principles, problems and application of amino acid digestibility in poultry. World Poultry Sci. J. 48, 232-246

Mack S., Bercovici D., De Groote G., Leclercq B., Lippens M., Pack M., Schutte J.B., Van Cauwenberghe S., 1999. Ideal amino acid profile and dietary lysine specification for broiler chickens of 20 to 40 days of age. Brit. Poultry Sci. 40, 257-265.

Parsons C.M., 1996. Digestible amino acids for poultry and swine. Anim. Feed Sci. Tech. 59, 147153

Poultry Feeding Standards. Recommended Allowances and Nutritive Value of Feedstuffs (in Polish), 1996. S. Smulikowska (Editor). $3^{\text {rd }}$ Edition. The Kielanowski Institute of Animal Physiology and Nutrition, Polish Academy of Sciences. Jabłonna (Poland), pp. 45-50

Rhone-Poulenc, 1993. Rhodimet Nutrition Guide. Feed Ingredients Formulation in Digestible Amino Acids. $2^{\text {nd }}$ Editon. Rhone-Poulenc Animal Nutrition, Antony Cedex (France), pp. 18-31

Waldroup P.W., 2000. Present status of use of digestible amino acid values in formulation of broiler diets: opportunities and obstacles. Asian-Austr. J. Anim. Sci. 13, Special Issue, 76-87

Wang X., Parsons C.M., 1998. Dietary formulation with meat and bone meal on a total versus a digestible or bioavailable amino acid basis. Poultry Sci. 77, 1010-1015 


\section{STRESZCZENIE}

Wskaźniki produkcyjne i wydalanie azotu u kurcząt brojlerów żywionych mieszankami paszowymi z udziałem lub bez mączki mięsno-kostnej i bilansowanymi według aminokwasów ogólnych lub strawnych

Celem doświadczenia było zbadanie możliwości poprawy wyników odchowu i ograniczenia wydalania azotu u kurcząt brojlerów, żywionych mieszankami paszowymi z udziałem lub bez udziału mączki mięsno-kostnej, w następstwie bilansowania składu aminokwasowego tych mieszanek w oparciu o strawne aminokwasy. Od 22 do 42 dnia życia kurczęta żywiono do woli izoenergetycznymi dietami: pszenno-kukurydziano-sojową zawierającą 8\% mączki mięsno-kostnej (M) lub dietą złożoną z kukurydzy, śruty sojowej, śruty rzepakowej oraz bobiku (P). Zawartość aminokwasów (AA) w dietach bilansowano zgodnie z zapotrzebowaniem kurcząt, biorąc do obliczeń ogólną zawartość AA w surowcach paszowych (diety Mt i Pt) lub zawartość AA strawnych (diety Md i Pd), uzupełniając ich zawartość w diecie AA krystalicznymi.

Dzienna ilość wydalanego azotu (wg N/szt. i \%N pobranego) przez kurczęta otrzymujące diety Pt i Pd była niższa niż otrzymujące diety z mączką mięsno-kostną. Niezależnie od składu diet podawanie mieszanek bilansowanych według strawnych AA istotnie poprawiło przyrosty masy ciała, wykorzystanie paszy oraz zwiększyło wartość Europejskiego Wskaźnika Wydajności odchowu kurcząt (EPI). Stosowanie mieszanek bilansowanych w oparciu o zawartość strawnych AA sprzyjało ograniczeniu wydalania azotu w odchodach ptaków.

Ograniczenia w stosowaniu mączek zwierzęcych sugerują potrzebę poszukiwań możliwości zwiększenia efektywności produkcji żywca drobiowego z użyciem pasz zawierających wyłącznie roślinne źródła białka. Uzyskane wyniki wskazują, że w przypadku mieszanki zawierającej śrutę sojową, śrutę rzepakową oraz bobik, bilansowanie składu aminokwasowego diety w oparciu strawne AA poprawia wskaźniki produkcyjne kurcząt brojlerów. 